\title{
Effect of Trichoderma harzianum on tomato plant growth and its antagonistic activity against Phythium ultimum and Phytopthora capsici
}

\author{
Muhammad Nazir Uddin*, Ubaid ur Rahman, Wajid khan, Nisar Uddin and Muhammad Muhammad
}

\begin{abstract}
Effect of Trichoderma harzianum was investigated on plant growth and inhibitory activity against Phythium ultimum and Phytopthora capsici under laboratory and greenhouse conditions. Data under lab conditions revealed that mycelial growth of both pathogens were inhibited by $T$. harzianum in vitro. The effect of $T$. harzianum on different plant growth parameters was assessed in the presence of $P$. ultimum and P. capsici. Fresh and dry shoot weight was reduced by both fungal strains. The fresh shoot weight was decreased by 38.8 and $44.4 \%$ in case of P. capsici and P. ultimum, respectively. T. harzianum improved the overall plant growth in the presence of $P$. ultimum and $P$. capsici. Histopathological observation of $P$. ultimum and $P$. capsici infected tissue of the root clearly indicated that both severely affected the epidermis and vascular bundle of the host plant. T. harzianum reduced the size of lesions caused by the two pathogens. Observation of hyphae interaction of the T. harzianum with pathogens demonstrated that it inhibited the entry of both pathogens to the vascular bundle of the host tissue. Furthermore, no effect was observed on the vascular bundle, pith and cortex of treated host plant inoculated with T. harzianum and pathogens.
\end{abstract}

Keywords: Histopathology, Trichoderma harzianum, Phythium ultimum, Phytopthora capsici, Bio control, Tomato

\section{Background}

Tomato (Lycopersicum esculantum Mill) is an important solanaceous vegetable crop all over the world including Pakistan. In Pakistan, its productivity and yield is low as compared to other developed countries due to many reasons (Heuvelink et al. 2003). Among one of them is soil-borne fungal diseases. Phythium ultimum and Phytopthora capsici are the most common destructive soil-borne pathogens having broad host range and causes severe crop loss to the farmers (Hausbeck and Lamour 2004).

P. capsici infects the underground part of plant, causing seed rot and seed blight as well as stem blight and overall stunted plant growth. Due to its severe infection, the fruits of the plant prematurely fall with low market value. $P$. ultimum usually

\footnotetext{
* Correspondence: nazirkhattak@yahoo.com
} University of Swat, Mingora, Pakistan destroys the conductive tissue of the root system which impairs translocation of water and mineral to the upper part of the plant producing stunted plant growth (Hendrix and Campbell 1973). Diseases caused by these soil-borne pathogens are complex in nature; therefore, their control and management is challenging task. Use of chemical pesticides is common and rapid mean of controlling soil-borne pathogens. However, the use of these chemicals are associated with negative impact like hazards to human, damage the beneficial soil micro-organisms, development of resistance by pathogen and also cause environmental pollution (Ragunathan and Divakar 1996).

Trichoderma species have long been identified and characterized as potential opportunistic, avirulent plant symbionts and biological agent against different soil-borne pathogens (Naseby et al. 2000; Harman et al. 2004). The important features of Trichoderma 

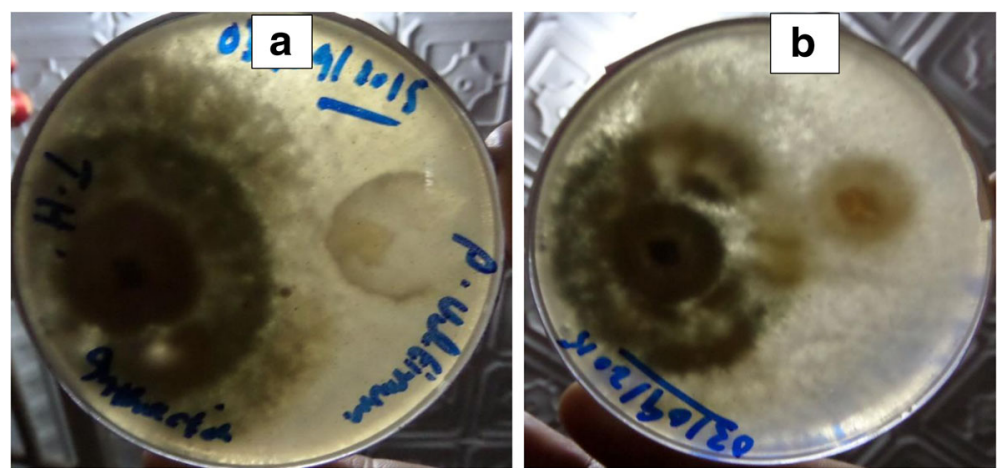

Fig. 1 a Interaction between Trichoderma harzianum and Phythium ultimum. b Interaction between Trichoderma harzianum and Phytopthora capsici

species are as follows: they rapidly colonize in the soil, favor wide range of environment, easy to isolate and culture, grow rapidly on many substrates, effective against a wide range of plant pathogens and rarely pathogenic to plants (Brotman et al. 2012; Khatabi et al. 2012). Histopathological study of host pathogen and biocontrol agent is very important to understand and visualize the efficacy of biological control agents $(\mathrm{BCA})$ at a cellular level. It provides the base for searching the control measures of different diseases.

The present study was conducted to assess the effect of Trichoderma harzianum and its inhibitory activity against $P$. ultimum and $P$. capsici on tomato plants under lab conditions. Moreover, the histopathology of host roots was also performed to explore the interactions of T. harzianum, $P$. ultimum, and P. capsici.

\section{Materials and methods}

Isolates of $P$. capsici, P. ultimum, and T. harzianum were obtained from the Department of Plant Pathology, The University of Agriculture, Peshawar, Pakistan.

\section{In vitro assay}

In vitro antagonistic activity of $T$. harzianum was tested against $P$. ultimum and $P$. capsici according to the standard procedure of Dennis and Webster (1971). Mycelial disc of $5 \mathrm{~mm}$ (diameter) of T. harzianum and pathogens were taken from 7-day-old culture and placed in a petri dish containing potato dextrose agar (PDA) at an equal distance in opposite direction. The control (pathogen alone) was also run in this assay. All the petri dishes were incubated in the dark at $28 \pm 2{ }^{\circ} \mathrm{C}$ for 5 days. In vitro antagonistic activity was measured in terms of percentage inhibition using the following formula.

$$
I=(C-T) / C \times 100
$$

where $I$ refers to percent inhibition, $C$ is control, and $T$ radial growth of pathogen $(\mathrm{mm})$ in the presence of $T$. harzianum.
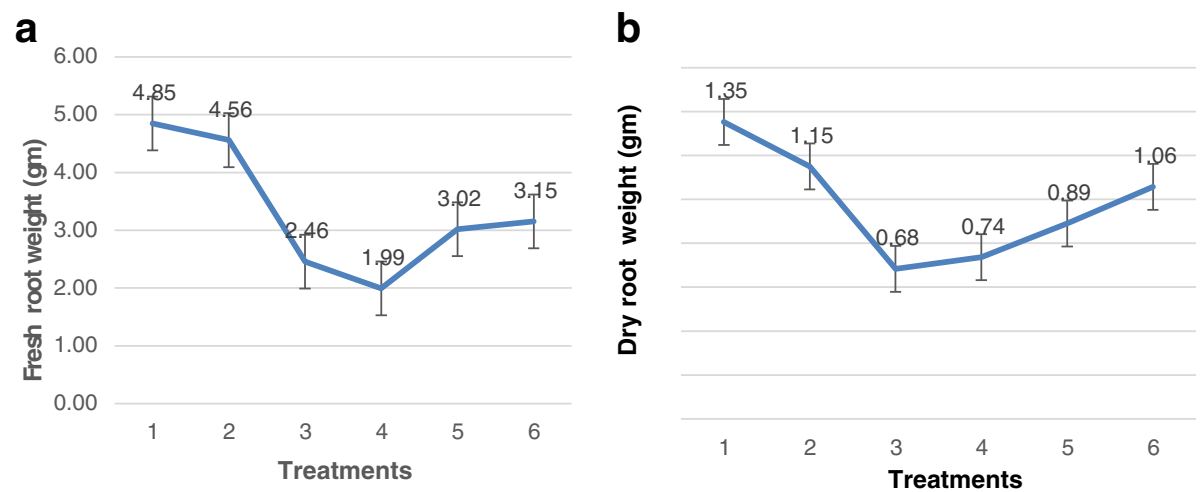

Fig. 2 Effect of soil infection with Trichoderma harzianum, Phythium ultimum, and Phytopthora capsici on tomato fresh weight (g) in a pot experiment (a). Effect of soil infestation with $T$. harzianum on $P$. ultimum and $P$. capsici on tomato dry root $(\mathrm{g})$ in a pot experiment (b). 1, uninoculated control (healthy); 2, T. harzianum (alone); 3 , inoculated with P. capsici (alone); 4, inoculated with P. ultimum (alone); 5, inoculated of $P$. capsici with T. harzianum; 6, P. ultimum with T. harzianum 

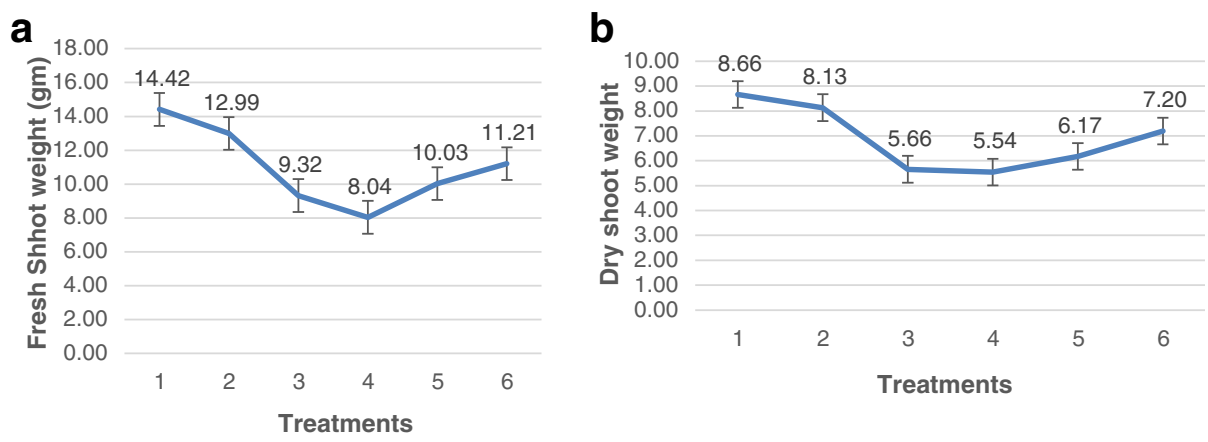

Fig. 3 Effect of soil infection with Trichoderma harzianum, Phythium ultimum, and Phytopthora capsici on tomato fresh shoot weight (g) in a pot experiment (a). Effect of soil infestation with T. harzianum on P. ultimum and P. capsici on tomato dry shoot weight (g) in a pot experiment (b). 1, uninoculated control (healthy); 2, T. harzianum (alone); 3, inoculated with P. capsici (alone); 4, inoculated with P. ultimum (alone); 5, inoculated of P. capsici with T. harzianum; 6, P. ultimum with T. harzianum

\section{Green house experiment}

Tomato germplasm, i.e. money maker, was obtained from Tarnab Agriculture Station, Peshawar, Pakistan. Nursery was raised in earthen pots from 3-week-old seedlings, transplanted to the 8.8inches diameter pots containing $2.5 \mathrm{~kg}$ of sterilized soil having sand, clay, and silt at a ratio of 2:1:1. The pure cultures of $P$. capsici, $P$. ultimum, and T. harzianum were refreshed on PDA media for 4 days at $25{ }^{\circ} \mathrm{C}$. The inoculum was prepared in potato dextrose broth and placed in a shaking incubator for 1 week at $25{ }^{\circ} \mathrm{C} \pm 2{ }^{\circ} \mathrm{C}$. The flask containing the culture media was then seeded with disks (7 $\mathrm{mm}$ diameter) of 4-day-old culture (Margaret et al. 2011). Holes were made in rhizosphere, and $5 \mathrm{ml}$ of conidial suspension of $107 \mathrm{ml}^{-1}$ was poured in each hole.

Both pathogens and biological agent were applied to the rhizosphere after 10 days of transplantation in a greenhouse of the Centre for Biotechnology and Microbiology (CB\&M), University of Swat, Pakistan.

The experiment was designed in randomized complete block design (RCBD) with six treatments and three replications. The treatments were categorized in to the following:

Un-inoculated control (healthy)

1. T. harzianum (alone).

2. Inoculated with $P$. capsici (alone)

3. Inoculated with P. ultimum (alone)

4. Inoculated with $P$. capsici and T. harzianum

5. P. ultimum with T. harzianum

The experiments were terminated after 40 days of inoculation. Plants of each pot were carefully uprooted, separately labeled, and brought to the laboratory. Data on different agronomic traits were recorded and analyzed by Statistic 8.1 Program. Means of the results were compared by using least significant difference (LSD) test (Steel et al. 1997).
Histopathological study was conducted. A comparative study of the root tissues in each treatment was carried out at 30 and 40 days after inoculation. The uprooted samples were thoroughly washed with tap water and excised into small pieces for fixation in F.A.A. (formaldehyde/acetic acid/alcohol, 3:1:6) and processed for histopathological studies (Sass 1958). Following fixation, the samples were dehydrated in $10,20,30,40$, and $50 \%$ ethanol. Roots were then transferred to butanol/ethanol/water solution prepared in the following ratio.

\begin{tabular}{lll}
\hline Butanol & Ethanol & Water \\
\hline 25 & 30 & 45 \\
55 & 25 & 20 \\
85 & 15 & 0 \\
100 & 0 & 0 \\
\hline
\end{tabular}

Roots were kept in each of the above solutions for $2 \mathrm{~h}$ at room temperature. Dehydrated root tissues were infiltrated and imbedded in paraffin wax at $52^{\circ}$ $\mathrm{C}$ for 10 days. Air bubbles were removed from the roots during the wax infiltration process. Sections of $12-\mu \mathrm{m}$ thicknesses were cut with a rotary microtome which were then affixed on slides with the help of Mayer's Albumin adhesive and stained with safranin and fast green (Sass 1958). The stained sections were mounted in Canada balsam and examined. Photographs were taken using Olympus digital camera at $4 \times, 10 \times$, and $100 \times$ magnifications.

\section{Results and discussion}

Genus Trichoderma is mostly used as biocontrol agent against different soil-borne pathogens (Ranasingh et al. 2006; Moubarak and Abdel-Monaim 2011). Trichoderma spp. as a biocontrol agent are known to compact the 


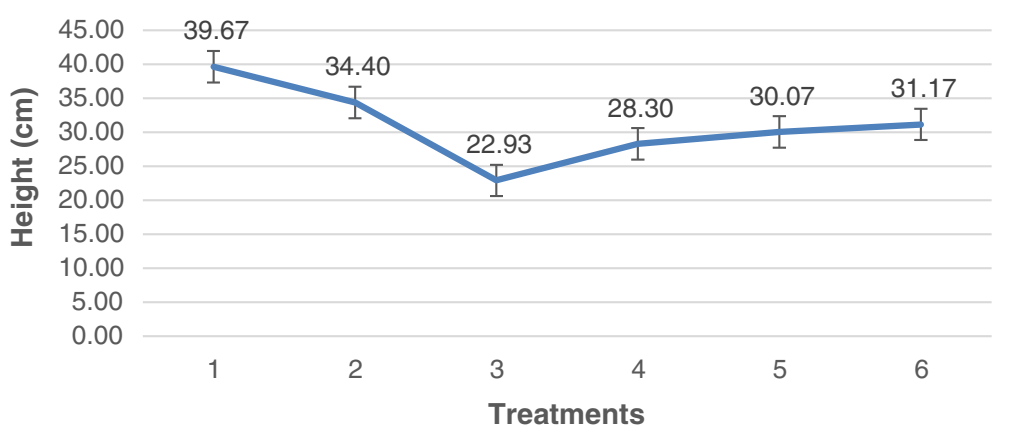

Fig. 4 Effect of soil infection with Trichoderma harzianum, Phythium ultimum, and Phytopthora capsici on tomato plant height (cm) in a pot experiment. 1, uninoculated control (healthy); 2, T. harzianum (alone); 3, inoculated with P. capsici (alone); 4, inoculated with P. ultimum (alone); 5 , inoculated of $P$. capsici with T. harzianum; $6, P$. ultimum with T. harzianum

plant pathogenic attack and improve the plant growth and yield by enhancing the growth hormones and increment of plant beneficial microbiome (Dubey et al. 2007; Khatabi et al. 2012).

Under lab condition, the T. harzianum inhibited the radial growth of both pathogens and showed more antagonistic activity against $P$. ultimum as compared to P. capsici (Fig. 1a, b). T. harzianum caused lysis of pathogen mycelium and thus inhibited its radial growth. Similar finding has also been reported in various studies (Ahmed et al. 1999; Rey et al. 2001). This antagonistic mechanism of $T$. harzianum involved the production of antibiotics, competition for nutrients, and production of hydrolytic enzymes (Howell 2003; Zeilinger and Omann 2007).

Under greenhouse conditions, both pathogens adversely affected the growth of host plant resulting in decreased fresh and dry weights of root and shoot (Spies 2011; Lamour et al. 2012). Figure 2a, b shows fresh and dry root weights in response to applied treatments. P. ultimum reduced the fresh root weight by $58.9 \%$ as compared to healthy control. Similarly, decreased in fresh root weight by $49.2 \%$ was noted in the presence of $P$. capsici. On the other hand, inoculation of $T$. harzianum increased the fresh root weight as compared to tomato plants inoculated with the two pathogens alone (Fig. 2a). P. ultimum inoculation reduced the dry root weight by $45.2 \%$. Similarly, the dry root weight was reduced by $49.6 \%$ in the presence of $P$. capsici as compared to healthy plants. Application of $T$. harzianum increased dry root weight in the presence of $P$. ultimum and $P$. capsici (Fig. 2b). Fresh and dry shoot weights were reduced by both pathogens. The fresh shoot weight was decreased by 38.8 and $44.4 \%$ in the case of $P$. capsici and $P$. ultimum, respectively. Similarly, $P$. ultimum inoculation reduced the dry shoot weight by $36 \%$ while $34.6 \%$ decrease in dry shoot was noted in the presence of P.capsici as compared to healthy plants. The artificial infestation of soil with $T$. harzianum significantly increased the fresh shoot weight in the soil infected with $P$. ultimum and P.capsici (Fig. 3a). However, dry shoot weight was less affected by $T$. harzianum inoculation (Fig. 3b). Both pathogens affect the height of plants as $P$. capsici and $P$. ultimum reduced the height by 42 and $28.6 \%$ respectively than in the healthy control (Fig. 4). This was reduced with artificial infestation of soil with $T$.
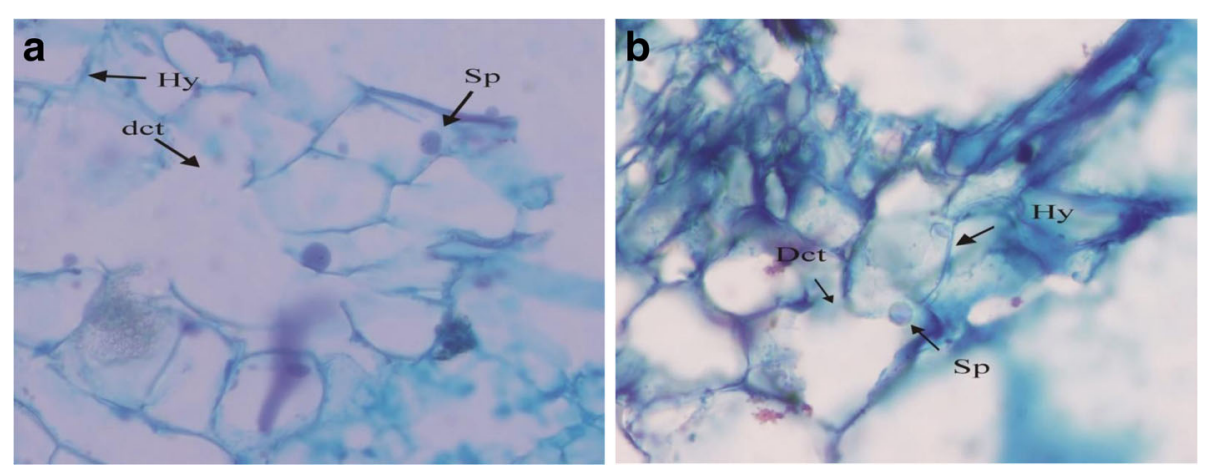

Fig. 5 a Histopathological interaction of Phythium ultimum with roots tissue of tomato plants (longitudinal section, $40 \times$ ). b Histopathological interaction of Phytopthora capsici with roots tissue of tomato plants (longitudinal section, $40 \times$ ) 

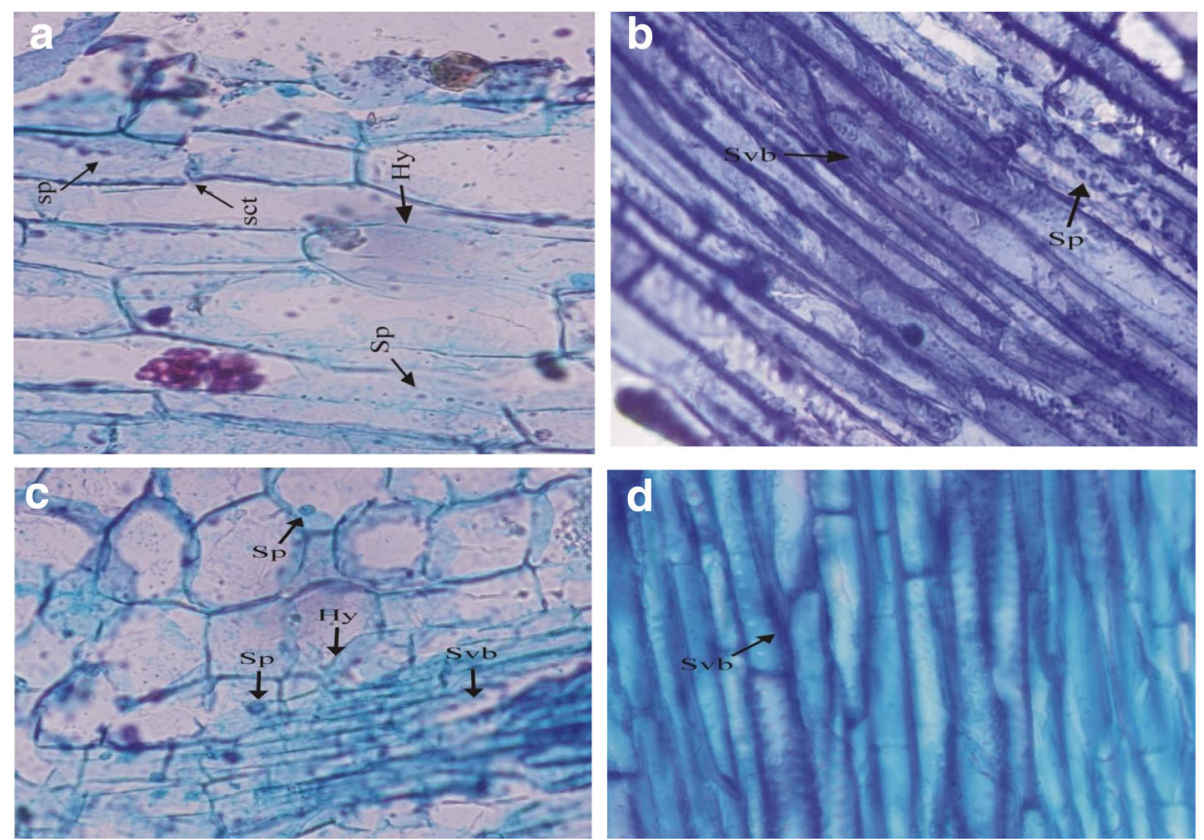

Fig. 6 a Histopathological interaction of T. harzianum and Phythium ultimum in cortex region of roots tissue of tomato plants (longitudinal section, $40 \times$ ). $\mathbf{b}$ Histopathological interaction of T. harzianum and Phythium ultimum in vascular bundle of roots tissue of tomato plants (longitudinal section, $40 \times$ ). c Histopathological interaction of Trichoderma harzianum and Phytopthora capsici in cortex region of roots tissue of tomato plants (longitudinal section, $40 \times$ ). $\mathbf{d}$ Histopathological interaction of Trichoderma and Phytopthora capsici in vascular bundle of roots tissue of tomato plants (longitudinal section, $40 \times$ )

harzianum in the presence of both pathogens. Improvement in agronomic traits of host plant in the presence of pathogen is attributed to T. harzianum that increased water uptake and translocation of nutrients (Hoyos-Carvajal et al. 2009).

The disease control by Trichoderma species involves multifarious interaction between the pathogen, biocontrol agent, and host plant (Harman 2006; Hoitink et al. 2006; Alfano et al. 2007). Histopathological interaction of $T$. harzianum with host and P. ultimum and $P$. capsici showed that the treatment involving only pathogens result in visible cellular alterations in the host root system. Data regarding histopathological study indicated that $T$. harzianum significantly reduced the size of the lesion caused by P. ultimum and P. capsici. The stained root sections of tomato plant revealed visible cellular alterations in different treatments (tomato plants inoculated with the two pathogens alone). The plants inoculated only with $P$. ultimum and $P$. capsici possessed damaged cells of the epidermis, cortex, and vascular bundles. Hyphae were seen in the epidermis, and spores were present in the damage area of both cortical and vascular regions of the root. The boundaries of several cells were broken, and thus, deformed xylem was not arranged longitudinally but was dispersed in a diffused and disconnected manner (Fig. 5a, b). But when both pathogens were applied separately in the presence of Trichoderma harzianum, hyphae were entered into the epidermis of tomato root without damaging the epidermal cells. The epidermal cells were intact and the tissues were healthy. Mycelium and spores of BCA were observed in the cortex region (Fig. 6a-d). Histopathological observation of their roots showed little damages to the cortex and vascular bundles which might be the excretion of $T$. harzianum that inhibit the population of both pathogens. Secondly, the biocontrol agent restricted the pathogen to cortex

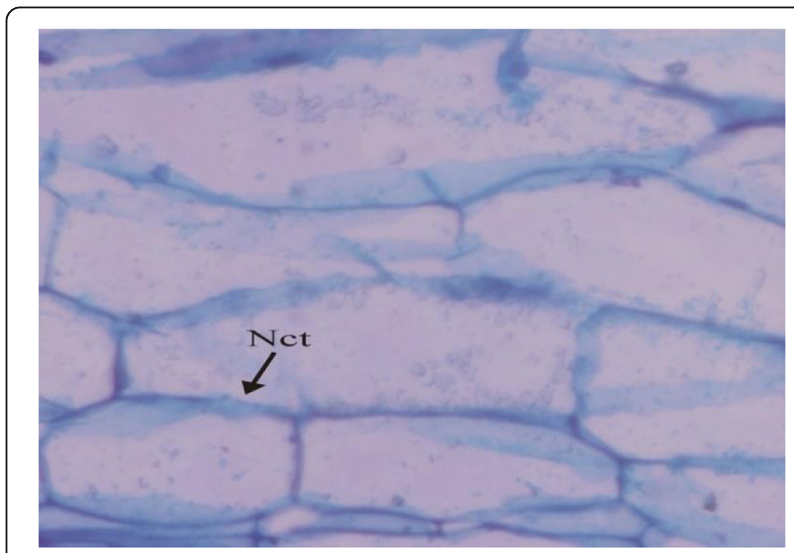

Fig. 7 Histopathological section of roots tissue of healthy tomato plants (longitudinal section, $40 \times$ ) 


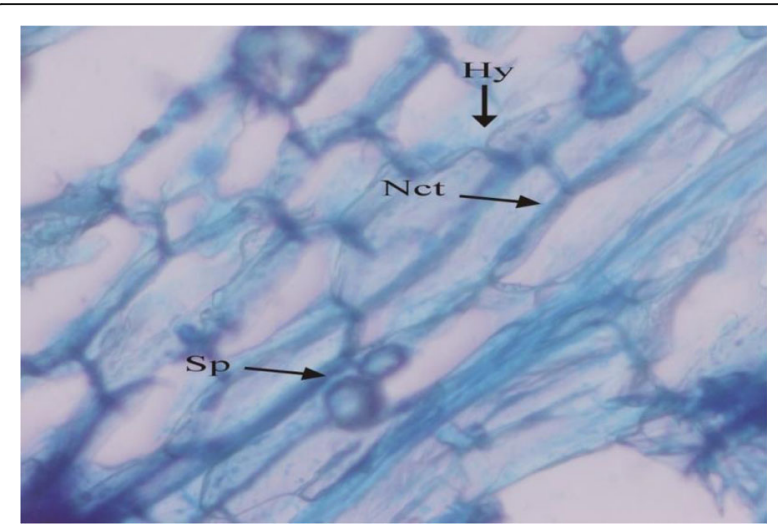

Fig. 8 Histopathological interaction of Trichoderma harzianum with roots tissue of tomato plants (longitudinal section, $40 \times$ )

region and hence the cells of vascular bundle remain intact and healthy and showed no malformation.

No histological changes were observed in longitudinal and transverse sections of stained roots of healthy plants (Fig. 7). However, for plants treated with T. harzianum alone, the biological control agent entered into the epidermis and cortex region of root tissue. Mycelium and dark round spores of $T$. harzianum were seen in those regions (Fig. 8).

\section{Conclusions}

The present evaluation clearly indicated that $T$. harzianum had strong antagonistic activity against $P$. ultimum than against $P$. capsici. Therefore, it could be recommended to be used for management of the diseases caused by P. ultimum and P. capsici.

\section{Acknowledgements}

We are thankful to the Higher Education Commission Pakistan (HEC) for providing financial support to this research project.

\section{Authors' contributions}

MNU conceived idea and designing of experiment. WK management of article, analysis of data and critical revision. UuR conduct experiments. NU participated in experiments design and coordination. MM drafting of manuscript. All authors read and approved the final manuscript.

\section{Competing interests}

The authors declare that they have no competing interests.

\section{Publisher's Note}

Springer Nature remains neutral with regard to jurisdictional claims in published maps and institutional affiliations.

Received: 23 October 2017 Accepted: 23 January 2018

Published online: 22 March 2018

\section{References}

Ahmed AS, Sanchez CP, Egea C, Candela ME (1999) Evaluation of T. harzianum for controlling root rot caused by Phytophthora capsici in pepper plants. Plant Pathol 48:58-65

Alfano G, Ivey MLL, Cakir C, Bos JIB, Miller SA, Madden LV, Kamoun S, Hoitink HAJ (2007) Systemic modulation of gene expression in tomato by Trichoderma hamatum 382. Phytopathology 97:429-437
Brotman Y, Lisec J, Meret M, Chet I, Willmitzer L, Viterbo A (2012) Transcript and metabolite analysis of the Trichoderma-induced systemic resistance response to pseudomonas syringae in Arabidopsis thaliana. Microbiology 158:139-146

Dennis C, Webster J (1971) Antagonistic properties of species groups of Trichoderma II. Production of non-volatile antibiotics. Trans Br Mycol Soc 57: $41-48$

Dubey SC, Suresh M, Birendra SS (2007) Evaluation of Trichoderma species against Fusarium oxysporum f.Sp. ciceris for integrated management of chickpea wilts. Biol. Control 40:118-127

Harman GE (2006) Overview of mechanisms and uses of Trichoderma spp. Phytopathology 96:190-194

Harman GE, Howell CR, Viterbo A, Chet I, Lorito M (2004) Trichoderma species opportunistic, avirulent plant symbionts. Nat Rev Microbiol 2:43-56

Hausbeck MK, Lamour KH (2004) Phytophthora capsici on vegetable crops: research progress and management challenges. Plant Dis 88:1292-1303

Hendrix FF, Campbell WA (1973) Pythium as plant pathogens. Annu Rev Phytopathol 11:77-98

Heuvelink E, Bakker MJ, Stanghellini C (2003) Salinity effects on fruit yield in vegetable crops: a simulation study. Acta Hortic 609:133-140

Hoitink HAJ, Madden LV, Dorrance AE (2006) Systemic resistance induced by Trichoderma spp.: interactions between the host, the pathogen, the biocontrol agent, and soil organic matter quality. Phytopathology 96:186-189

Howell CR (2003) Mechanisms employed by Trichoderma species in the biological control of plant diseases: the history and evolution of current concepts. Plant Dis 87:4-10

Hoyos-Carvajal L, Ordua S, Bissett J (2009) Growth stimulation in bean (Phaseolus vulgaris L.) by Trichoderma. Biol Control 51:409-416

Khatabi B, Molitor A, Lindermayr C, Pfiffi S, Durner J, Wettstein D, Kogel KH, Schäfer P (2012) Ethylene supports colonization of plant roots by the mutualistic fungus Piriformospora indica. PLoS One 7:e35502

Lamour KH, Stam R, Jupe J, Huitema E (2012) The oomycete broad-host-range pathogen Phytophthora capsici. Mol Plant Pathol 13:329-337

Margaret WM, Ethel OM, Sheila A, Okoth, Joyce MJ (2011) Inoculation of tomato seedlings with T. harzianum and Arbuscular Mycorrhizal fungi and their effect on growth and control of wilt in tomato seedlings. Braz J Microbiol 42:508513

Moubarak MY, Abdel-Monaim MF (2011) Effect of bio-control agents on yield, yield components and root rot control in two wheat cultivars at New Valley region, Egypt. J. Cereals Oilseeds 2:77-87

Naseby DC, Pascual JA, Lynch JM (2000) Effect of biocontrol strains of Trichoderma on plant growth, P. ultimum populations, soil microbial communities and soil enzyme activities. J Appl Microbiol 88:161-169

Ragunathan V, Divakar BJ (1996) Integrated pest managemeent strategies. In: Gunasekaran M, Weber DJ (eds) Molecular biology of the biological control of pests and disease of plants. CRC Press, Florida, pp 191-194

Ranasingh N, Saturabh A, Nedunchezhiyan M (2006) Use of Trichoderma in disease managemant. Orissa Review, September-October, pp 68-70

Rey M, Delgado-Jarana J, Benítez T (2001) Improved antifungal activity of a mutant of T. harzianum CECT 2413 which produces more extracellular proteins. Appl Microbiol Biotechnol 55:604-608

Sass JE (1958) Botanical Microtechnique, 3rd ed. The lowa State College Press, Ames, lowa, p 228

Spies CFJ, Mazzola M, Botha WJ, Van der Rijst M, Mostert L, McLeod A (2011) Oogonial biometry and phylogenetic analyses of the Pythium vexans species group from woody agricultural hosts in South Africa reveal distinct groups within this taxon. Fungal Biol 115:157-168

Steel RGD, Torrie JH, Dickey DA (1997) Principles and procedures of statistics. A biometrical approach, 3rd Ed. McGraw Hill Book Co. Inc, New York, pp 172177

Zeilinger S, Omann M (2007) Trichoderma biocontrol: signal transduction pathways involved in host sensing and mycoparasitism. Gene Regul Syst Bio 1:227-234 